\title{
Verb Naming and Comprehension in Patients with Alzheimer's Disease: Focusing on Instrumentality of Action Verbs
}

\author{
Sangeun Shin ${ }^{\mathrm{a}}$, Miseon Kwon ${ }^{\mathrm{b}}$, Jae-Hong Lee ${ }^{\mathrm{b}}$, Hyun Sub Sim ${ }^{\mathrm{a}}$ \\ ${ }^{a}$ Department of Communication Disorders, Ewha Womans University, Seoul, Korea \\ ${ }^{b}$ Department of Neurology, Asan Medical Center, University of Ulsan College of Medicine, Seoul, Korea
}

Correspondence: Sangeun Shin, PhD Department of Communication Disorders, Ewha Womans University, 52 Ewhayeodae-gil, Seodamun-gu, Seoul 03760, Korea

Tel: $+82-2-3277-2120$

Fax: +82-2-3277-2122

E-mail: newvil78@gmail.com

Received: April 5, 2017

Revised: May 18, 2017

Accepted: May 31, 2017

This research was extracted from the part of Master's thesis (2007) of the first author.

\begin{abstract}
Objectives: The present study aimed to elucidate the nature of semantic impairment in action verbs focusing on instrumentality, as revealed in a verb naming and a comprehension tasks completed by healthy elderly and patients with Alzheimer's disease (AD). Methods: Twelve patients with mild and moderate $A D$ and 12 healthy elderly participated in the study. Forty action verbs from 20 instrument verbs and 20 non-instrument verbs were selected for both confrontation naming and word-picture matching tasks. Task effect as well as semantic effect of instrument verbs was analyzed by using two-way mixed ANOVA and post-hoc analyses. Results: Verb naming and comprehension abilities in patients with $A D$ were significantly poorer than healthy elderly. Unlike the healthy elderly, AD patients showed significantly lower naming scores for instrument verbs than for non-instrument verbs. Meanwhile, no instrumentality effect was found in the word-picture matching task for either group. Conclusion: These results confirm previous studies that report verb naming and comprehension deficits in patients with $A D$, and extend the finding to the semantic category of instrument verbs. Naming deficits in instrument verbs seem to be related to the loss of the semantic feature relationship between verbs and their corresponding nouns. The feature-based framework in semantic memory is discussed further.
\end{abstract}

Keywords: Alzheimer's disease, Verb naming, Verb comprehension, Instrumentality, Semantic memory
알츠하이머성 치매(Alzheimer's disease, $\mathrm{AD}$ ) 환자는 점진적인 어휘의미체계의 손상으로 의미기억에서 단어를 인출하는 데에 어 려움을 보인다(Appell, Kertesz, \& Fisman, 1982; Bayles, Tomoeda, \& Trosset, 1990; Bowles, Obler, \& Albert, 1987; Grossman \& Mickanin, 1994; Jin, Choi, \& Lee, 2016; Kim, Kim, \& Na, 1997; Kim, Kim, Namkoong, Kim, \& Kim, 2006; Lee, 2002; Martin \& Fedio, 1983; Park, Jeong, \& Kang, 2005; Tulving, 1972; Williams, Mack, \& Henderson, 1989). AD환자의 단어인출 연구는 주로 명사와 동사에 초 점을 맞추어 활발하게 이루어졌는데 몇몇 연구에 따르면 동사산출 에 더 어려움을 보이는 것으로 보고되고 있어 명사와는 다른 의미 구조를 가진 동사에 주목할 필요가 있다(Cappa et al., 1998; Druks et al., 2006; Kim \& Thompson, 2004; Robinson, Grossman, White-
Devine, \& D'Esposito, 1996; White-Devine, Grossman, Robinson, Onishi, \& Biassou, 1996).

명사는 계층적인 의미구조(hierarchical semantic organization) 를 갖기 때문에 상위의 의미범주(예: 음식)는 하위의 범주들(예: 과 일, 채소, 육류 등)과 연결되어 있고 각 하위범주에는 해당 어휘들 이 저장되어 있다(예: 사과, 배는 과일 범주에, 오이, 배추는 채소 범 주에 포함). 같은 의미범주 내에서는 어휘들 간에 의미자질(semantic features)들이 공유되어 있기 때문에(예: 사과와 배는 공통적으 로 ‘음식' '먹다', ‘달콤하다', '씨', '껍질' 등의 의미자질을 공유) 목표 어휘를 인출하기 위한 활성화(activation) 정도가 부족하더라도 공 유된 다른 어휘의 활성화된 의미자질이 영향을 주어 인출에 도움 을 받을 수 있게 된다(Dell, 1986). 반면에 동사는 명사와는 달리 상 
대적으로 계층적이지 않기 때문에, 어휘들 간의 공통적인 의미자 질수가 적은 편이며 이로 인해 목표어휘의 인출 시 다른 어휘의 활 성화로부터 도움을 받는 데에 상대적인 제한이 발생한다(Miller \& Fellbaum, 1991). 따라서 AD환자는 의미기억(semantic memory) 의 손상으로 인해 상대적으로 공유하는 의미자질이 적은 동사에 대해 명사보다 더 많은 인출실패를 보이게 된다(Druks et al., 2006).

동사의 의미적 특징이 이름대기능력에 끼치는 영향은 도구성 (instrumentality)에 따른 $\mathrm{AD}$ 환자의 동사표현능력에서 확인해볼 수 있다(Parris \& Weekes, 2001, 2006). 도구성이란 동작을 수행할 때에 도구를 필요로 하는지의 여부를 말하는 것으로 도구의 필요 없이 신체부위를 사용하여 동작할 수 있는 비도구동사(non-instrument verb)와(예: 잡다) 기구나 도구를 필요로 하는 도구동사 (instrument verb)로 구분된다(예: 박다) (Jonkers \& Bastiaanse, 2007). 도구동사의 경우 비도구동사와 달리 구문적으로 수단을 나 타내는 논항을 필요로 하며(Kim \& Thompson, 2000; Kiss, 2000; Thompson, Lange, Schneider, \& Shapiro, 1997), 의미적으로는 도 구로 사용되는 사물에 대한 어휘의미체계와도 연결되어 있기 때문 에(Jonkers \& Bastiaanse, 2007; Kemmerer \& Tranel, 2000; Parris \& Weekes, 2001) 인출의 어려움을 야기한다고 보고 있다.

실제로 Parris와 Weekes (2001)는 사물표현능력에 심한 결함을 보이고 동사이름대기능력은 상대적으로 보존되어 있는 한 치매환 자의 사례에서 비도구동사에 비해 도구동사의 표현능력이 유의미 하게 낮은 것을 보고한 바 있다. 이러한 결과는 도구성의 효과(instrumentality effect)가 치매환자에게도 중요한 영향을 끼치고 있다 는 것을 보여주며 사물표현능력의 결함이 도구동사의 표현능력과 관련되어 있다는 것을 제시한다. Parris와 Weekes (2006)의 집단비 교연구를 살펴보면 $\mathrm{AD}$ 집단과 정상노인집단 모두 도구동사의 이름 대기능력이 비도구동사에 비해 낮았으며 $\mathrm{AD}$ 집단은 정상집단보다 도구동사의 수행이 유의미하게 낮았다. 이러한 결과는 $\mathrm{AD}$ 집단의 경우 정상집단과 달리 사물에 대한 기능적 지식(functional knowledge)의 감소와 함께 도구동사가 갖는 감각과 기능적 자질에 대한 지식 손상이 두드러지기 때문에 유의미한 결함 양상으로 나타난다 는 것을 말해준다(Parris \& Weekes, 2001, 2006). 또한 노인성으로 인해 어휘의미체계로 효과적으로 접근하는 데에 어려움이 발생하 기 시작하는 정상노인의 경우(Kim, Hwang, Kim, \& Kim, 2013; Mackay, Connor, Albert, \& Obler, 2002; Ramsay, Nicholas, Au, Obler, \& Albert, 1999), 비록 치매환자와 같이 의미기억이 손상되지 는 않았다 하더라도 도구성이 산출에 영향을 주었음을 보여준다.

사물에 대한 지식과 도구동사의 동작에 대한 지식의 연관성은 자질 기반의 프레임워크(feature based framework)를 통해서도 설
명이 가능하다(Almor et al., 2009). 자질 기반의 프레임워크는 명사 혹은 동사에 대한 의미지식이 의미자질들과 개념들 사이의 연결에 의해 표상된다고 본다(Bird, Howard, \& Franklin, 2000; Garrard, Ralph, Hodges, \& Patterson, 2001; Miller \& Fellbaum, 1991; Parris \& Weekes, 2001; Vigliocco, Vinson, Damian, \& Levelt, 2002; Vinson \& Vigliocco, 2002; Vinson, Vigliocco, Cappa, \& Siri, 2003). 각 개념들은 공유하는 자질들에 의해 다른 개념들과 관계를 맺게 되 는데, 공유되는 자질들의 수가 많을수록 두 개념 간의 의미적 유사 성은 높아지게 되며(Rips, Shoben, \& Smith, 1973; Tversky, 1977), 공유하는 자질의 성격에 따라 개념의 유사성뿐만 아니라 반대의 미, 혹은 상위 및 하위어 관계도 갖게 된다. 개념들 간의 관계가 공 유되는 자질에 영향을 받는다는 맥락에서 사물에 대한 정보를 필 요로 하는 도구동사는 비도구동사보다 명사와의 관련성이 높기 때 문에 사물의 의미표상(semantic representation)이 도구동사의 개 념 활성화에 큰 역할을 하게 된다(Almor et al., 2009). 실제로 관련 연구에 따르면 도구동사를 머리 속에서 처리하는 과정에서 도구로 사용되는 사물의 활성화도 함께 발생하는 것으로 알려져 있다(Ferretti, McRae, \& Hatherell, 2001; Koenig, Mauner, \& Bienvenue, 2003). 따라서 비도구동사와 달리 도구동사는 동작에 대한 지식과 함께 사물에 대한 지식 또한 이중으로 요구하기 때문에 도구동사 의 인출이 더 손상된 것으로 보고 있다(Almor et al., 2009).

동사 및 사물에 대한 의미지식의 손상이 도구동사의 산출에 영 향을 준다면 동사이해는 어떠할까? 전반적인 동사이해능력과 관 련하여 몇몇 연구에서는 $\mathrm{AD}$ 환자에게서 정상집단과는 구별되는 이해능력의 결함이 나타난다고 보고하고 있다(Grossman, Mickanin, Onishi, \& Hughes, 1996; Kim \& Lee, 2016; Kim \& Thompson, 2004; Martin \& Fedio, 1983; Masterson et al., 2007; White-Devine et al., 1996). 그러나 $\mathrm{AD}$ 환자의 이름대기능력에서 나타나는 도구성 에 따른 수행 차이가 이해능력으로도 결부되어 나타나는지에 대해 서는 아직까지 연구된 바가 없다. 만약 연구를 통해 의미적 범주가 동사의 이해능력에도 영향을 주는 것으로 나타난다면 이 또한 자 질 기반의 프레임워크를 사용하여 설명 가능할 것으로 보인다. 프 레임워크의 주요한 특징 중 하나는 개념들과 자질들간의 연결이 점 진적으로 손실(graceful degradation)된다는 것이기 때문에(Almor et al., 2009; Aronoff et al., 2006; Bonilla \& Johnson, 1995; Farah \& McClelland, 1991; Flanagan, Copland, Chenery, Byrne, \& Angwin, 2013; Ober \& Shenaut, 1999) 퇴행성질환으로 인해 의미자질 의 수가 점진적으로 감소하면서 나타나는 $\mathrm{AD}$ 환자의 표현과 이해 의 서로 다른 결함을 설명할 수 있게 된다. 만약 동사산출에서 나타 나는 도구성의 영향이 동사이해에서도 나타난다면 $\mathrm{AD}$ 환자의 의 
미자질의 수 감소는 도구동사와 사물을 연결하는 의미자질의 상 당수가 손실되어 산출과 이해에 모두 영향을 주는 것으로 풀이될 수 있을 것이다. 반면에 동사이해능력이 도구성의 영향을 받지 않 는다면 이는 의미자질의 손상 정도가 표현과 이해에 다르게 영향 을 끼친다는 것을 의미할 것이다.

본 연구에서는 $\mathrm{AD}$ 환자의 동사표현능력과 이해능력에 대한 이 해를 확장하고자 도구성에 초점을 맞추어 다음의 두 과제를 통하 여 정상집단과의 수행을 비교하였다. 동사표현능력은 다양한 신경 계 질환 환자를 대상으로 시각적인 자극을 보고 단어회상능력과 어휘능력을 간단하고 정확하게 측정할 수 있는 검사방법으로 활용 되고 있는 대면이름대기검사(confrontation naming test)방법을 채 택하였고(Lezak, 1995), 동사이해능력은 선행연구에서 자주 사용 하는 방법인 낱말-그림짝맞추기과제(word-picture matching task) 를 통하여 살펴보았다(d'Honincthun \& Pillon, 2008; Rhee, Antiquena, \& Grossman, 2001; White-Devine et al., 1996). 도구성의 영 향을 논하기에 앞서 연구에 사용된 자극어가 혼재효과-(confounding effect)를 일으켜 기존의 학설과는 다르게 피험자들의 동사표 현 및 이해능력에 영향을 끼칠 가능성을 배제할 수 없기 때문에 도 구성을 떠나 두 과제에서의 반응을 집단별로 비교하는 것을 포함 하였다. 세부 연구목표는 다음과 같다.

첫째, 동사에 대한 대면이름대기과제와 낱말-그림짝맞추기과제 에서 $\mathrm{AD}$ 집단과 정상집단 간에 점수 차이가 있는지 살펴본다.

둘째, 대면이름대기과제에서 도구성에 따라 $\mathrm{AD}$ 집단과 정상집 단 간에 점수 차이가 있는지 살펴본다.

셋째, 낱말-그림짝맞추기과제에서 도구성에 따라 $\mathrm{AD}$ 집단과 정 상집단 간에 점수차이가 있는지 살펴본다.

\section{연구방법}

\section{연구대상}

본 연구는 정상노인 12 명 평균연령 $=72.17$ 세, 표준편차 $=5.51$; 교 육년수 $=12.25$, 표준편차 $=3.86$ )과 $\mathrm{AD}$ 진단을 받은 노인 12 명(평균 연령 $=74.08$ 세, 표준편차 $=5.82$; 교육년수 $=10.75$, 표준편차 $=5.50$ ) 을 대상으로 실험을 실시하였다. $\mathrm{AD}$ 환자는 서울 소재 종합병원 신 경과 외래환자 및 노인전문병원에 입원한 환자 중에서 모집하였다.

National Institute of Neurological and Communicative Disorders and Stroke and Alzheimer's Disease and Related Disorders Association (NINCDS-ADRDA: McKhann et al., 1984)의 기준에 따라 신경과 전문의가 $\mathrm{AD}$ 로 진단한 자를 대상으로 하였으며, Clinical Dementia Rating (CDR; Morris, 1993) 척도에 따라 CDR 1 (경도치
매)과 $\mathrm{CDR} 2$ (중등도치매)에 해당하는 환자를 포함하였다. 중증도 별 모집인원은 각각 6 명이다.

정상노인과 $\mathrm{AD}$ 환자 모두 한국어가 모국어이고 서울 및 경기도 에 거주하며, 무학이 아닌 55세 이상의 연령(고령자 고용촉진법 기 준)인 사람을 포함하였다. 정상노인은 신경 및 정신적 병력이 없으며 K-MMSE (Korean version of Mini Mental State Examination; Kang, $\mathrm{Na}, \& \mathrm{Hahn}, 1997)$ 선별검사에서 24점 이상을 얻은 사람을 포함하 였고, 치매환자의 경우 $\mathrm{AD}$ 외에 다른 신경 및 정신적 병력을 갖고 있지 않는 것을 조건으로 하였다.

두 집단의 인구 특징의 차이는 카이스퀘어검사(Chi-square test) 와 독립표본 $t$-검정(independent samples $t$-test)을 통하여 살펴보았 고 분석 결과 성별 $\left(\chi^{2}=0.000, p=1.000\right)$, 연령 $\left(t_{(22)}=-.828, p=.416\right)$, 교육년수 $\left(t_{(22)}=.773, p=.448\right)$ 에 있어서 차이가 없는 것으로 나타났 다. 그러나 본 검사 실시 전, 두 집단의 기본적인 인지 및 언어능력 차이를 살펴보기 위하여 실시한 K-MMSE와 K-BNT (Korean-Boston Naming Test; Kim \& Na, 1997)에 있어서는 $\mathrm{AD}$ 집단이 정상노 인집단보다 유의하게 수행이 낮은 것으로 나타났다(각각 $t_{(12.369)}=$ $\left.5.581, p<.001 ; t_{(15.734)}=4.165, p=.001\right)$. 각 집단의 자세한 특징은 Table 1 에 제시되어 있다.

\section{실험과제 및 절차}

어휘선정

대면이름대기과제와 낱말-그림짝맞추기과제는 도구동작 항목 20 개와 비도구동작 항목 20 개로 구성된 총 40 개의 동일한 문항으 로 구성되었다(각각 Appendix 1과 Appendix 2 참조). 모든 항목은 "현대 국어 사용 빈도 조사: 한국어 학습용 어휘 선정을 위한 기초 조사"(Cho, 2002)에서 보고된 빈도순위 5만 5천 이내의 순우리말 로 된 고빈도 동작동사이면서, Kim (2003)의 "등급별 국어교육용 어휘” 기준에서 1 등급(기초어휘)과 2 등급(정규 교육 이전)에 해당 하는 어휘들로 구성하여 학력과 어휘친숙도가 미치는 영향을 최소

Table 1. Demographic characteristics of participants

\begin{tabular}{lccc}
\hline Characteristic & Control (N=12) & $\mathrm{AD}(\mathrm{N}=12)$ & $p$-value \\
\hline Age (yr) & $72.17(5.51)$ & $74.08(5.82)$ & $.416^{\mathrm{a}}$ \\
Sex (male:female) & $5: 7$ & $5: 7$ & $1.000^{\mathrm{b}}$ \\
Education (yr) & $12.25(3.86)$ & $10.75(5.50)$ & $.448^{\mathrm{a}}$ \\
K-MMSE & $28.42(1.51)$ & $18.42(6.02)$ & $.001^{\mathrm{a}}$ \\
K-BNT & $45.17(7.38)$ & $24.50(15.52)$ & $<.001^{\mathrm{a}}$ \\
\hline
\end{tabular}

Values are presented as mean (SD).

$A D=$ Alzheimer's disease; K-MMSE = Korean version of Mini Mental State Examination; K-BNT = Korean-Boston Naming Test.

alndependent samples $t$-test, ${ }^{b}$ Chi-square test. 
화하였다. 모든 단어는 2-3개의 음절수로 제한하였고 복합동사는 제외하였다. 도구동작 항목과 비도구동작 항목의 논항(argument) 수는 2-3개로 구성하였는데 이는 $\mathrm{AD}$ 환자의 동사 이름대기능력이 논항수가 1 개인 동사와 2 개인 동사 간에는 유의한 차이가 있으나 논항수 2 개(예: 영희가 연필을 잡다)와 3 개(예: 영희가 연필을 철수에 게 주다) 사이에는 차이가 없는 것을 근거로 한다(Kim \& Thompson, 2004). 낱말-그림짝맞추기과제의 경우 목표어휘와 함께 3 개의 방해어휘가 함께 제시되었다. 방해어휘도 목표단어 선정기준을 그 대로 따르되 목표어휘와 의미적으로 연관된 단어 1 개, 음운적으로 연관된 단어 1 개, 그리고 의미적, 음운적으로 무관한 단어 1 개로 구 성하였다. 대면이름대기과제와 낱말-그림짝맞추기과제의 항목 순 서는 유사무작위(pseudo-randomization)로 제시되었다.

목표어휘에 대응되는 그림자료는 대학병원의 임상에서 사용하 는 동작그림 자료를 사용하였으며 예비실험을 통해 정상성인 5 인 으로부터 모두 정반응을 얻은 것들로만 구성하였다. 대면이름대기 과제에 사용된 그림자료는 K-BNT의 검사자료와 동일한 크기(가로 $20 \mathrm{~cm} \times$ 세로 $14.5 \mathrm{~cm}$ )의 흑백의 선그림으로 제작하였고, 낱말-그 림짝맞추기과제의 그림자료는 대면이름대기과제에 사용된 그림과 동일 자료를 사용하되 $\mathrm{A} 4$ 크기의 4 분할컷으로 크기를 줄여 제작하 였다(Appendix 3 참조).

\section{실험절차}

실험은 독립되고 조용한 공간에서 개별적으로 실시되었다. 실험 참여자에게 연구동의를 얻은 후 대상자의 기본정보를 얻기 위한 면담과 선별검사가 이루어진 뒤에 본 실험과제인 대면이름대기과 제와 이해과제가 실시되었다. 낱말-그림짝맞추기과제의 경우 연구 자가 말하는 목표단어를 듣고 적절한 그림 문항을 선택하는 방식 으로 이루어지기 때문에 과제수행 중에 목표단어에 노출되는 경우 가 생긴다. 이러한 노출이 후행하는 과제수행에 영향을 끼칠 수 있 기 때문에 모든 실험참여자에 대하여 대면이름대기과제를 먼저 실 시하고 이후에 낱말-그림짝맞추기과제를 실시하였다. 대상자가 보 인 반응은 모두 반응기록지에 기록하였으며 추후 신뢰도 평가를 위하여 디지털 캠코더로 녹화하였다.

대면이름대기과제의 시행규칙은 K-BNT를 따르되 검사시작 전 에 지시사항을 줄 때에는 충분히 대상자가 과제를 이해할 수 있도 록 자세한 예시와 함께 다음과 같이 설명하였다. "지금부터 여러 가 지 동작이 그려진 그림을 보여 드리겠습니다. 그림을 보시고 무엇을 하고 있는지 말씀해주시면 됩니다. 예를 들어서(연습문항(1) 그림 을 제시하면서) 이 그림에서는 무엇을 하고 있지요? (반응을 기다린 후) 네, 물을 따르고 있지요. 그렇게 뭘 하고 있는지 말씀해주십시
오. (연습문항(2)를 실시한다). 자 이제 준비되셨으면 시작하겠습니 다. 뭘 하고 있지요?”라고 말했다. 대상자의 반응처리는 정해진 시 간 내에 정확한 목표어휘를 대답하는 경우 정반응으로 간주하였 고, 15 초가 지나서도 무반응을 보이거나 15 초 내에 모른다고 대답 한 경우 그리고 그림의 의미와 관련 없는 반응을 보인 경우에는 오 반응으로 처리하였다. 목표어휘의 의미를 내포하여 에둘러 말하는 경우와 의미적으로 근접한 어휘를 말한 경우에는 " $\bigcirc \bigcirc$ 말고 다른 말로 뭐라고 하나요?” 또는 “구체적으로 뮈라고 하죠?”라고 물어 서 한 번 더 대답할 수 있는 기회를 주었다. 대상자가 두 번째 기회에 서 목표단어를 말하면 정반응으로 처리하고 그 외의 반응에 대해 서는 모두 오반응 처리하였다. 연구의 목적상 피험자들의 자발적인 동사인출과정에서 도구성이 영향을 주는지를 살펴보고자 하였으 므로 오반응에 대하여 의미적, 음운적 단서를 제공하였을 때 보이 는 2 차 반응은 본 연구의 분석에 포함하지 않았다.

낱말-그림짝맞추기과제는 검사자가 구두로 목표 낱말을 제시하 면 대상자가 그것을 듣고 4 개의 그림 중에서 해당하는 그림을 가리 키는 방식으로 진행되었다. 연습문항을 통해 지시사항을 이해했는 지를 확인한 후 시작하였으며, 특별히 제한시간은 두지 않았다. 단, 잘 모를 경우 모른다고 반응하도록 요구하였다. 대상자가 한번 더 어휘를 들려줄 것을 요청하거나 자극이 제시된 후에도 반응이 나 타나지 않는 경우, 목표어휘를 한 번 더 구어로 제시하였다.

\section{자료분석 및 통계처리}

자료분석은 SPSS version 24 (IBM, Armonk, NY, USA) 프로그 램을 사용하여 반복측정 이원분산분석(repeated two-way ANO$\mathrm{VA}$ )을 실시하였다. 유의수준 .05에서 검증하되, 구형성(sphericity) 검정을 충족하지 않는 경우, Greenhouse-Geisser 분석을 통하여 유의성을 검증하였다.

집단과 과제유형 간의 관계를 살펴보는 연구목표 1 을 수행하기 위해, 집단유형(2)은 피험자 간 요인(between subjects factor)으로, 과제유형(2)은 피험자내 요인(within subjects factor)으로 하여 종 속변수인 과제 총점수(도구동작에 대한 점수+비도구동작에 대한 점수)에 대한 분석이 이루어졌다. 상호작용효과가 유의할 경우, 이 에 대한 사후검정으로 단순주효과(simple main effect)를 살펴보 기 위해 독립표본 $t$-검정(independent samples $t$-test)과 대응표본 $t$ 검정(paired samples $t$-test)을 실시하였다. 이때 다중비교로 인한 제 1 종 오류(Type I error)를 보정하기 위해 본페로니 교정(Bonferroni correction)을 적용한 유의수준에서 검정하였다.

연구목표2 및 연구목표 3 과 관련해서는 대면이름대기과제와 낱 말-그림짝맞추기과제에서의 집단과 도구성 간의 관계를 살펴보기 
위하여 집단유형(2)은 피험자 간 요인(between subjects factor)으 로, 도구성(2)은 피험자내 요인(within subjects factor)으로 하였다. 종속변수는 도구동작에 대한 점수 또는 비도구동작에 대한 점수 로 지정하였다. 마찬가지로 상호작용효과가 유의할 경우 단순주효 과를 살펴보기 위해 보정한 유의수준에서 독립표본 $t$-검정과 대응 표본 $t$-검정을 실시하였다.

신뢰도

동사대면이름대기과제에서의 피험자 반응에 대한 신뢰도는 전 체 대상자의 $25 \%$ 에 해당하는 자료를 무작위로 추출하여 실시되었 다. 국내 언어병리학 과정을 수료한 석사대학원생 1 명이 녹화 비디 오를 보며 독립적으로 과제평가를 하였다. 연구자와의 평가 결과를 비교하여 일치한 항목수를 일치하거나 일치하지 않은 모든 항목수 로 나눈 후 100 을 곱하여 검사자 간 신뢰도를 구한 결과 $99.8 \%$ 로 높 게 나타났다. 낱말-그림짝맞추기과제는 연구자가 피험자의 반응을 기입하는 과정에서의 오류가 없는지를 확인하는 차원에서 모든 피 험자의 그림 지적하기 반응에 대하여 녹화 비디오를 보며 검사자 내 신뢰도를 산출하였다. 검사 결과 $100 \%$ 의 신뢰도를 보이는 것으 로 나타났다.

\section{연구결과}

\section{집단 간 동사이름대기와 낱말-그림짝맞추기과제 점수 비교}

과제유형별로 각 집단이 보인 두 과제의 수행 점수는 Table 2에 제시되어 있고, 도표는 Figure 1에 제시되어 있다. 낱말-그림짝맞추 기과제의 경우 총 40 점 만점에서 $\mathrm{AD}$ 집단은 평균점수 31.25 점(표준 편차 $=6.73$ )으로 정상노인집단의 평균 39.33점 $($ 표준편차 $=1.15)$ 에 비해 약 8.08 점 낮았다. 대면이름대기과제의 경우 총 40 점 만점 중 $\mathrm{AD}$ 집단은 23.25 (표준편차 $=10.70$ )으로 정상노인집단의 평균점수

Table 2. Verb naming task and verb comprehension task scores

\begin{tabular}{lll}
\hline & Control $(\mathrm{N}=12)$ & $\mathrm{AD}(\mathrm{N}=10)$ \\
\hline Verb naming & & \\
Non-transitive & $18.58(1.38)$ & $13.17(5.42)$ \\
Transitive & $17.92(1.56)$ & $10.08(5.58)$ \\
$\quad$ Total & $36.50(2.75)$ & $23.25(10.70)$ \\
Verb comprehension & & \\
$\quad$ Non-transitive & $19.67(.65)$ & $15.92(3.40)$ \\
Transitive & $19.67(.65)$ & $15.33(3.52)$ \\
Total & $39.33(1.15)$ & $31.25(6.73)$ \\
\hline
\end{tabular}

Values are presented as mean (SD). $\mathrm{AD}=$ Alzheimer's disease.
인 36.50점(표준편차 $=2.75$ )보다 약 13.25 점 낮았다. 집단 내에서 살펴보면 두 과제 간의 평균점수 차이는 두 집단 모두 이해과제의 수행점수가 이름대기과제보다 더 높게 나타났으며, 과제 간의 평균 점수차이는 $\mathrm{AD}$ 집단이 정상노인집단보다 더 큰 것으로 나타났다.

집단(2)과 과제유형(2)에 따른 2요인 혼합분산분석 결과, 집단의 주효과가 통계적으로 유의하였고 $\left(F_{(1,22)}=17.686, p<.001\right)$, 과제유 형의 주효과도 통계적으로 유의하였다 $\left(F_{(1,22)}=49.076, p<.001\right)$. 집 단과 과제유형 간 상호작용도 통계적으로 유의하였다 $\left(F_{(1,22)}=11.163\right.$, $p=.003)$.

유의한 상호작용효과에 대한 단순주효과를 살펴보기 위해 사후 검정을 실시하였다. 보정한 유의수준 .01 (즉.05/4 comparisons. 소 수점 둘째자리에서 절하)에서 각 과제별 집단 간의 수행차이를 독 립표본 $t$-검정을 이용하여 분석한 결과 $\mathrm{AD}$ 환자가 정상노인에 비해 동사이해하기과제에서 $\left(t_{(11.647)}=4.101, p=.002\right)$ 그리고 대면이름대 기과제에서 $\left(t_{(12.443)}=4.154, p=.001\right)$ 모두 유의하게 낮은 수행을 보 였다. 또한 각 집단별 과제 간의 수행차이를 대응표본 $t$-검정을 이 용하여 분석한 결과 대면이름대기과제의 점수가 낱말-그림짝맞추 기과제 점수보다 정상노인집단 $\left(t_{(11)}=-3.328, p=.007\right)$ 과 $\mathrm{AD}$ 집단 $\left.t_{(11)}=-6.197, p<.001\right)$ 모두에서 유의하게 낮은 것으로 나타났다.

\section{대면이름대기과제에서 도구성에 따른 집단 간 차이}

비도구동사와 도구동사에 대해 각 집단이 보인 두 과제의 점수 는 Table 2에 제시되어 있고, 도표는 Figure 2에 제시되어 있다. 비도

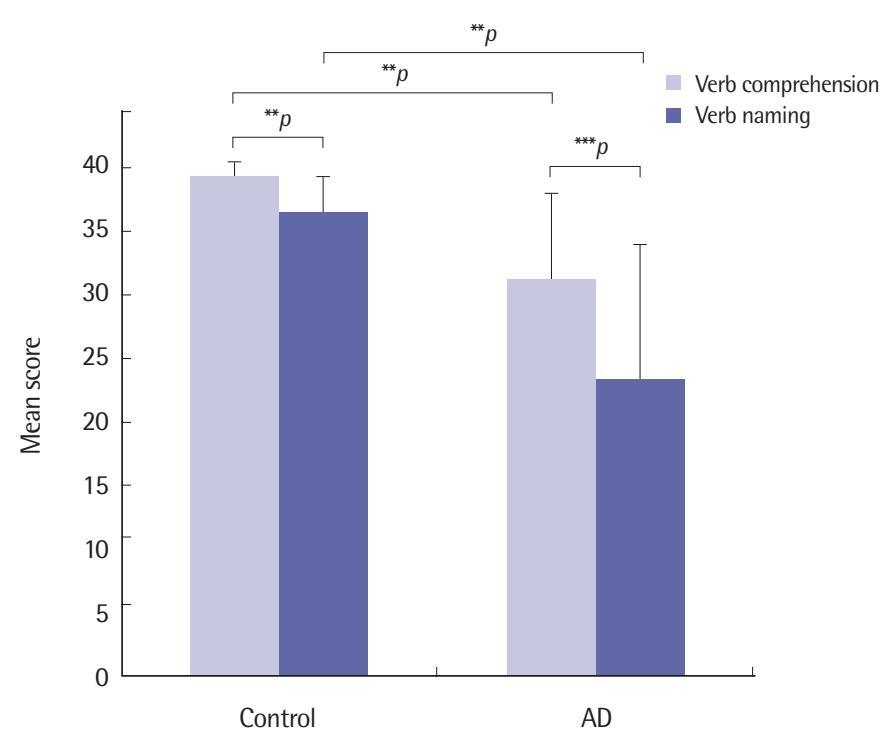

Figure 1. Mean scores of verbs in the confrontation naming and word-picture matching tasks in the control and $\mathrm{AD}$ groups.

$\mathrm{AD}=$ Alzheimer's disease.

${ }^{* *} p<.01,{ }^{* * *} p<.001$. 


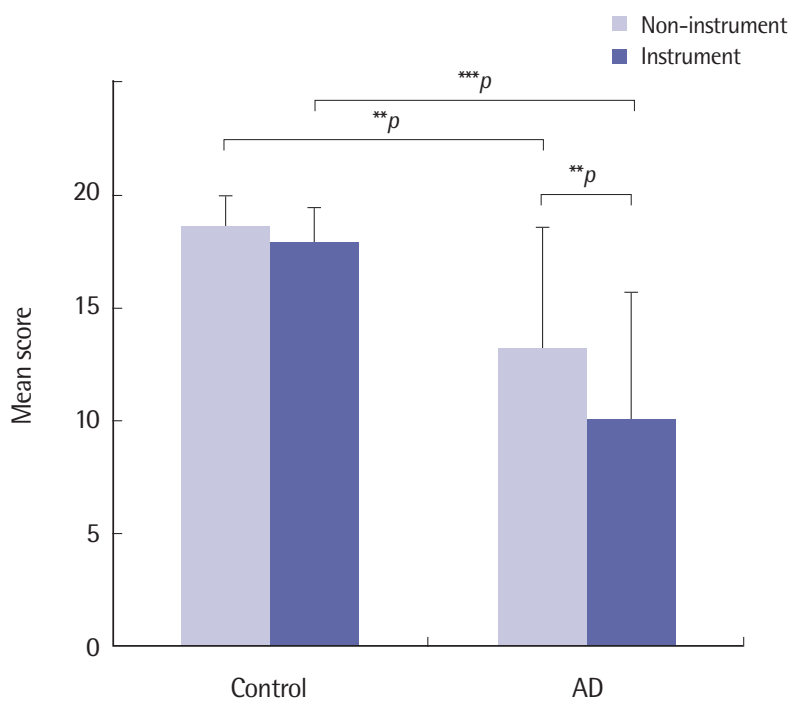

Figure 2. Mean scores of non-instrument and instrument verbs in the confrontation naming task in the control and $\mathrm{AD}$ groups.

$\mathrm{AD}=$ Alzheimer's disease.

${ }^{* *} p<.01,{ }^{* * *} p<.001$.

구동작의 경우 20 점 만점에 $\mathrm{AD}$ 집단은 평균점수 13.17 점(표준편차 $=5.42)$ 으로 정상노인집단의 평균 18.58 점 $($ 표준편차 $=1.38)$ 에 비해 약 5.41점 낮았다. 도구동작의 경우 20점 만점에 $\mathrm{AD}$ 집단은 10.08 점 (표준편차 $=5.58$ )으로 정상노인집단의 평균점수인 17.92점(표준편 차 $=1.56$ )보다 약 7.84 점 낮아, 집단 간의 점수 차이가 더 벌어졌다. 대면이름대기과제에서의 이 점수차이는 낱말-그림짝맞추기과제에 서 집단 간 보였던 점수차이인 4.34점보다 더 큰 수치이다. 비도구동 작과 도구동작 간의 평균점수차이는 두 집단 모두 도구동작에서의 수행점수가 비도구동작에 비해 낮아지는 것으로 나타났는데, $\mathrm{AD}$ 집 단이 정상노인집단보다 점수차이가 더 벌어지는 것으로 나타났다.

대면이름대기과제에 대한 집단(2)과 도구성(2)에 따른 2요인 혼 합분산분석 결과, 집단의 주효과가 통계적으로 유의하였고 $\left(F_{(1,22)}=\right.$ $17.252, p<.001)$, 도구성의 주효과도 통계적으로 유의하였다 $\left(F_{(1,22)}=\right.$ $21.689, p<.001)$. 집단과 과제유형 간 상호작용도 통계적으로 유의 하였다 $\left(F_{(1,22)}=9.008, p=.007\right)$.

유의한 상호작용효과에 대한 단순주효과를 살펴보기 위해 사후 검정을 실시하였다. 보정한 유의수준 .01에서 각 과제별 집단 간의 수행차이를 독립표본 $t$-검정을 이용하여 분석한 결과 $\mathrm{AD}$ 환자가 정상 노인에 비해 비도구동작 대면이름대기과제에서 $\left(t_{(12.416)}=3.353\right.$, $p=.006)$ 그리고 도구동작에 대해 $\left(t_{(12.716)}=4.680, p<.001\right)$ 모두 유 의하게 낮은 수행을 보였다. 각 집단별 과제 간의 수행차이를 대응 표본 $t$-검정을 이용하여 분석한 결과에서는 정상노인집단의 경우 도구동작 점수과 비도구동작 점수 간에는 유의한 차이가 없었으

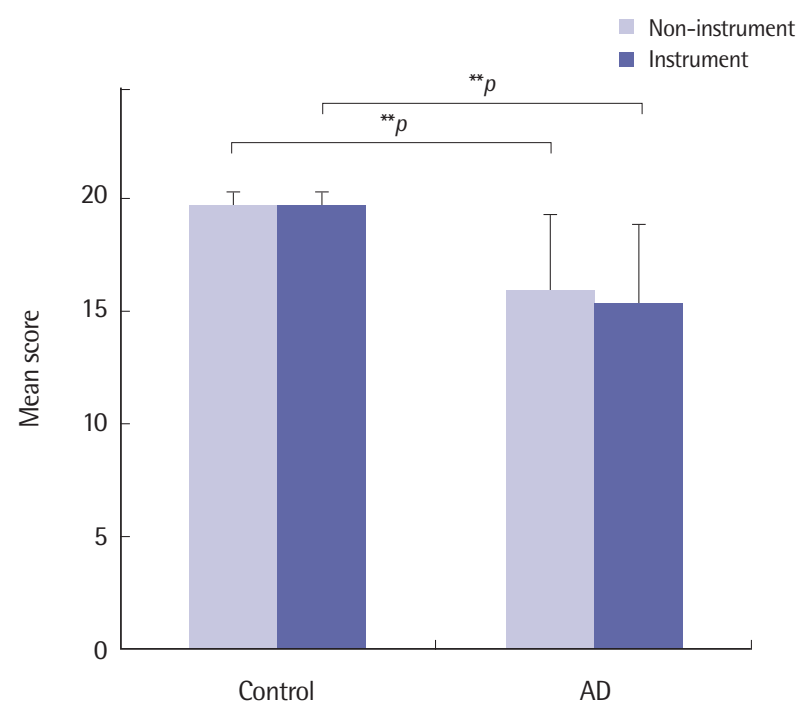

Figure 3. Mean scores of non-instrument and instrument verbs in the wordpicture matching task in the control and $A D$ groups.

$A D=$ Alzheimer's disease

${ }^{* *} p<.01$.

나 $\left(t_{(11)}=-2.152, p=.054\right), \mathrm{AD}$ 집단의 경우 도구동작의 이름대기과 제 점수가 비도구동작보다 유의하게 낮았다 $\left(t_{(11)}=-4.149, p=.002\right)$.

\section{낱말-그림짝맞추기과제에서 도구성에 따른 집단 간 차이}

비도구동작과 도구동작에 대해 각 집단이 보인 두 과제 점수는 Table 2에 제시되어 있고, 도표는 Figure 3에 제시되어 있다. 비도구 동작의 경우 20 점 만점에 $\mathrm{AD}$ 집단은 평균점수 15.92점(표준편차 $=3.40$ )으로 정상노인집단의 평균 19.67점(표준편차 $=.65)$ 에 비해 약 3.75점 낮았다. 도구동작의 경우 20점 만점에 $\mathrm{AD}$ 집단은 15.33 (표준편차 $=3.52$ )으로 정상노인집단의 평균점수인 19.67점(표준편 차 $=.65)$ 보다 약 4.34 점 낮아, 비도구동작에 비해 도구동작에서 점 수차이가 다소 벌어지는 것으로 나타났다. 비도구동작과 도구동작 에 대한 평균점수는 정상노인집단의 경우 평균점수가 동일하였고, $\mathrm{AD}$ 집단의 경우 거의 비슷한 수준이었다.

낱말-그림짝맞추기과제에 대한 집단(2)과 도구성(2)에 따른 2요 인 혼합분산분석 결과, 집단의 주효과가 통계적으로 유의하였으나 $\left(F_{(1,22)}=16.815, p<.001\right)$, 도구성의 주효과는 통계적으로 유의하지 않았다 $\left(F_{(1,22)}=1.365, p=.255\right)$. 집단과 과제유형 간 상호작용도 통 계적으로 유의하지 않았다 $\left(F_{(1,22)}=1.365, p=.255\right)$.

\section{논의 및 결론}

본 연구에서는 $\mathrm{AD}$ 환자의 동사 의미기억에 대한 이해를 확장하 
고자 의미범주 중 하나인 도구성에 초점을 맞추어 대면이름대기과 제와 낱말-그림짝짓기과제에서의 수행을 정상노인과 비교하였다. 첫 번째 연구목표와 관련하여 $\mathrm{AD}$ 환자의 동사이름대기능력과 이 해능력은 정상노인에 비하여 저하된 것으로 나타나 선행연구와 일 치된 결과를 보여주었다(Cappa et al., 1998; Druks et al., 2006; Kim \& Lee, 2016; Martin \& Fedio, 1983; Masterson et al., 2007; Parris \& Weekes, 2006; Robinson et al., 1996; White-Devine et al., 1996). 이 는 도구동작과 비도구동작 항목으로 구성된 의미범주에 있어서도 일관된 결과가 나타난다는 것을 보여준다. 두 집단 모두 이해보다 는 산출능력에서의 결함이 보다 두드러졌으나 $\mathrm{AD}$ 환자의 동사산 출과 이해능력 간의 격차는 정상노인보다 더욱 벌어졌다. 이는 정 상노인의 경우에는 어휘에 대한 지식이 저장되어 있는 의미기억으 로의 접근에 어려움을 보이기 때문이며(Kim et al., 2013; Mackay et al., 2002; Ramsay et al., 1999) AD환자의 경우에는 어휘에 대한 지식 자체의 손상이 진행되어 보다 심한 능력 결함으로 이어졌기 때문인 것으로 보인다(Druks et al., 2006; Kim \& Thompson, 2004; Tulving, 1972; White-Devine et al., 1996).

두 번째 연구목표는 도구성에 따라 $\mathrm{AD}$ 집단과 정상집단 간에 대 면이름대기과제의 수행에서 차이가 있는지 살펴보는 것이었다. 환 자의 도구 및 비도구동사 산출능력은 정상노인보다 낮았으며 이러 한 차이는 도구동사에서 더욱 두드러지게 나타나 선행연구와 일치 된 결과를 보여주었다(Parris \& Weekes, 2006; Parris \& Weekes, 2001). 도구동사의 수행이 낮은 이유는 사물을 수단으로 필요로 하 기 때문에 이러한 의미구문적 복잡성이 영향을 준 것으로 보인다 (Kim \& Thompson, 2000; Thompson et al., 1997). 자질 기반의 프 레임워크 상에서 보면 성공적인 도구동사 인출을 위해서는 사물과 동사의 의미표상 관계가 공유되는 자질에 의해잘 유지되고 활성화 되어야 하는데 $\mathrm{AD}$ 환자의 경우 공유되는 의미자질의 손상으로 의 미표상 관계가 약해져서 비정상적인 산출로 나타난 것으로 볼 수 있다(Almor et al., 2009; Miller \& Fellbaum, 1991; Vigliocco et al., 2002). 이러한 특징은 도구성과 비도구성 항목으로 구분하여 살펴 보는 것 이상으로 같은 의미범주 내에서 살펴보았을 때에도 동일하 게 나타나는 것으로 확인되었다. 가령 공통적인 의미자질을 갖는 '찢다(비도구성)' '자르다(도구성)', 베다(도구성)'에 대해 $\mathrm{AD}$ 환자 들은 비도구동사보다는 도구동사에서 더 높은 오류를 보이는 것 으로 나타났다.

도구동사의 인출과정에서 나타난 $\mathrm{AD}$ 환자의 의미기억 손상은 이들의 오류반응에서도 그 특징을 찾아볼 수 있다. 본 연구에서 $\mathrm{AD}$ 집단과 정상노인집단 모두 의미적 오류가 다른 음소적 오류나 기타 오류(에두르기, 무반응, 모르겠다, 시지각오류 등)에 비해 높
은 출현 빈도를 보였는데 도구동사 항목에 대한 $\mathrm{AD}$ 환자의 의미적 오류의 수 $(\mathrm{N}=43)$ 는 정상노인의 3 배 이상에 달하는 것으로 나타 난 반면 비도구동사는 비슷한 빈도로 출현하였다 $(\mathrm{N}=18)$. 이러한 결과는 경도와 중등도의 $\mathrm{AD}$ 환자들이 의미적 대치오류를 가장 많 이 보였다는 Kim과 Thompson (2004)의 연구결과와 일치하며, 시 지각적 오류와 의미적 대등오류가 높게 나타났다는 Druks 등(2006) 의 보고와도 부분적으로 일치한다. 본 연구에서 나타난 $\mathrm{AD}$ 환자의 의미적 오류는 목표단어의 상위범주로 대치하여 말하거나(예: 목 표어 [빨다] $\rightarrow$ "먹는다"; 목표어 [베다] $\rightarrow$ "보리쌀을 자르는거죠"), 목표어휘의 의미와 연결되는 어휘로 대치하는 경우(예: 목표어 [끌 다] $\rightarrow$ "밀고 들어가는 거"; 목표어 [젓다] $\rightarrow$ "타는거, 이렇게 가는 거 지”)를 많이 포함하였다. 기타오류 중에는 모르겠다는 반응과 에둘 러 말하는 경우(목표어 [쏘다] $\rightarrow$ "쓰윽하면서 하는거 아니에요?"; 목표어 [뚫다] $\rightarrow$ "이거 하는거지 이거”), 그리고 무반응이 자주 출 현하였는데 이러한 오류유형들은 의미적 대치오류와 함께 $\mathrm{AD}$ 환 자의 도구동사에 대한 의미기억체계가 손상되었음을 뒷받침해준다.

그러나 도구성의 영향이 $\mathrm{AD}$ 환자 뿐만 아니라 정상노인에게도 나타났던 선행연구와는 다르게(Parris \& Weekes, 2006) 본 연구에 서는 $\mathrm{AD}$ 환자만이 그 영향을 받는 것으로 나타났다. 비록 정상노인 의 도구동사에 대한 평균점수가 비도구동사보다 낮기는 하였으나 선행연구처럼 통계적으로 유의하지 않았던 이유는 본 연구가 피험 자들의 학력과 어휘에 대한 친숙도가 주는 영향을 낮추기 위하여 고빈도 위주의 비교적 인출이 쉬운 단어들로 구성된 도구 및 비도 구 항목들을 사용하였기 때문으로 판단된다. 따라서 정상집단에 서는 두 동사군에서 모두 정반응률이 높게 나타나 변별력이 다소 상쇄된 것으로 보인다. 그러나 치매환자가 이토록 친숙한 고빈도의 도구동사에 대하여 정상노인보다 더 큰 인출의 어려움을 보인다는 것을 밝힘으로써 의미범주에 민감하게 영향을 받는 $\mathrm{AD}$ 환자의 동 사산출 특성에 대한 경험적 자료를 제공하였다는 데에 의의가 있 다. 즉, 노인성 단어인출 결함과 구분되는 $\mathrm{AD}$ 환자의 병리적인 의미 손상을 진단할 때에 도구동사의 이름대기과제가 언어장애의 한 지 표로서 활용될 수 있다는 가능성을 제시하였다.

마지막으로 도구성에 따라 $\mathrm{AD}$ 집단과 정상집단 간에 낱말-그림 짝맞추기과제의 수행에서 차이가 있는지를 살펴본 결과 $\mathrm{AD}$ 환자 는 정상노인에 비해 도구성에 상관없이 이해결함이 나타나는 것으 로 확인되었다. 이러한 결과는 의미적인 기억손상이 단어의 산출 을 필요로 하지 않는 과제수행에도 영향을 준다는 선행연구의 결 과를 뒷받침하며(Huff et al., 1986; Martin \& Fedio, 1983; WhiteDevine et al., 1996) 특정 의미범주를 벗어나 일반적으로 $\mathrm{AD}$ 환자 가 보이는 동사이해능력의 결함에 대한 선행연구 결과와 일치한다 
(Grossman et al., 1996; Kim \& Lee, 2016; Kim \& Thompson, 2004; Martin \& Fedio, 1983; Masterson et al., 2007; White-Devine et al., 1996). 도구성이 $\mathrm{AD}$ 환자의 동사산출에는 영향을 주는 반면 이해 에는 정상노인과 마찬가지로 영향을 주지 않는 것으로 나타나면서 동사와 사물의 의미표상 관계가 비록 손상 되었다 하더라도 이러 한 손상이 산출과 이해의 처리과정에 다르게 영향을 줄 수 있다는 것이 밝혀졌다. 이는 의미개념들과 자질들간의 연결이 점진적으로 손실된다는 자질 기반 프레임워크를 통해 설명 가능할 것이다(Almor et al., 2009; Aronoff et al., 2006; Bonilla \& Johnson, 1995; Farah \& McClelland, 1991; Flanagan et al., 2013; Ober \& Shenaut, 1999). 즉, $\mathrm{AD}$ 환자의 경우 의미기억의 손상으로 개념과 의미자질 간의, 혹 은 개념들 간의 연결이 점진적으로 감소하게 되는데, 비록 도구동 사의 활성화에 필요한 사물과 동사간의 공유된 의미자질이 손상되 었다 하더라도 그 손상된 정도에 따라 점진적인 결함이 도구동사 의 표현과 이해에 따라 다르게 나타날 수 있다는 것이다. $\mathrm{AD}$ 의 중 증도에 따라 도구동사의 산출과 이해가 어떻게 다르게 나타나는지 에 대해서는 추후 연구가 필요하나 $\mathrm{AD}$ 증상이 더 진행될수록 의미 자질의 수 또한 더욱 감소하게 되어 도구동사와 사물을 연결하는 의미자질의 상당수가 손실되고, 이로 인해 산출과 이해에 모두 영 향을 주게 될 것으로 추론할 수 있다.

요약하면, 본 연구는 도구동사와 비도구동사에 대한 $\mathrm{AD}$ 환자의 동사산출과 이해능력을 살펴봄으로써 도구성에 대한 부족한 연구 에 경험적 자료를 제공하였다. 또한 도구라는 의미범주가 동사이해 에서는 동사산출과 다른 양상으로 영향을 준다는 것을 밝혀냄으 로써 $\mathrm{AD}$ 환자의 동사이해와 산출 간의 관계를 보다 폭넓게 이해하 는 데에 기여하였다. 임상적으로는 노인성으로 인한 단어인출의 결 함과 구분되는 $\mathrm{AD}$ 환자의 도구동사 인출의 결함을 $\mathrm{AD}$ 진단 시 활 용할 수 있을 것으로 보인다. 아울러 경도와 중등도의 $\mathrm{AD}$ 환자들 이 보이는 단어인출의 결함을 효과적으로 중재할 수 있는 치료기법 의 마련과 함께 사물과 동사가 공유하는 의미자질의 손상을 지연 시킬 수 있는 방안이 있는지에 대한 검토가 필요할 것으로 보인다. 가령 사물과 동사의 의미관계를 실물 또는 사진을 통하여 강화하 는 방법이 얼마나 효과적인지를 살펴보는 연구가 필요하며 의미손 상이 이미 많이 진행된 환자의 경우 보완대체적인 방법을 사용하 여 효과적인 단어인출을 도울 수 있는 방법이 무엇인지를 고민해 볼 필요가 있다.

임상적인 의의에도 불구하고 몇 가지 제한점이 있다. 우선 실험 에 사용된 그림자극은 임상에서 활용되는 자료이기 때문에 정상 성인 5 인에 대해서만 예비실험을 실시하여 $100 \%$ 명명일치도를 보 인 것을 과제에 포함시켰다. 그러나 실험 자극의 보다 높은 타당성
을 확보하기 위해서는 더 많은 샘플수를 기반으로 예비실험을 실시 할 필요성이 있어 보인다. 또한 본 연구는 치매노인에게서 나타나는 전반적인 동사인출능력을 이해하기 위한 목적으로 중증도를 구분 하지 않고 CDR 1 과 2 를 하나의 집단으로 묶어서 살펴보고 있기 때 문에 병의 진행 정도가 과제에 미치는 영향을 설명해주고 있지 못 하다. 중증도가 심해질수록 동사이름대기 능력이 저하된다는 보 고가 있으므로(Beber, Cruz, \& Chaves, 2015), 추후연구에서는 이 것이 도구성의 효과와 어떠한 관계가 있는지를 살펴볼 필요가 있겠 다. 또한 정상노인과 $\mathrm{AD}$ 환자의 경계선에 있는 경도인지장애(mild cognitive impairment) 환자를 포함시켜 이들 간의 동사인출능력 을 의미손상의 연장선 상에서 살펴보는 연구도 $\mathrm{AD}$ 의 도구 동사에 대한 의미손상 정도를 이해하는 데에 도움을 줄 것으로 보인다.

마지막으로 본 연구에서는 동사항목에 대해서만 수행을 분석하 였기 때문에 각 도구동작 동사에 직접적으로 사용되는 사물명사 에 대한 의미기억과의 관계를 살펴보지는 않았다. 비록 별도의 통 계분석을 통하여 각 피험자의 K-BNT 점수와 도구동사의 정반응 수 간의 매우 높은 양적 상관관계가 나타났으나 본 연구결과에서 언급하지 않기로 한 이유는 K-BNT에 포함된 항목에는 도구로 사 용되는 사물뿐만 아니라 그렇지 않은 명사들을 다수 포함하고 있 으며, 수단으로 사용되는 명사의 경우에도 저빈도 단어가 상당수 포함되어 있어서 정확하게 수단과 도구동사에 대한 언어능력을 파 악하기가 어렵기 때문이다. 아울러 K-BNT에 사용된 사물의 경우 본 실험에 사용된 도구동사 항목에 반드시 연결되는 사물은 아니 기 때문에 높은 상관이 나타났다 하더라도 그것을 해석하는 데에 있어서 오히려 더 큰 주의를 요한다. 따라서 공식검사인 K-BNT에 서 나타나는 명사이름대기능력이 도구와 비도구의 의미범주에 따 라 수행에 차이를 보이는지를 그에 해당하는 도구동사와 비도구동 사 항목과 연결하여 살펴보는 후속연구가 필요할 것으로 보인다.

\section{REFERENCES}

Almor, A., Aronoff, J. M., MacDonald, M. C., Gonnerman, L. M., Kempler, D., Hintiryan, H., ... \& Andersen, E. S. (2009). A common mechanism in verb and noun naming deficits in Alzheimer's patients. Brain and Language, 111, 8-19.

Appell, J., Kertesz, A., \& Fisman, M. (1982). A study of language functioning in Alzheimer patients. Brain and Language, 17, 73-91.

Aronoff, J. M., Gonnerman, L. M., Almor, A., Arunachalam, S., Kempler, D., \& Andersen, E. S. (2006). Information content versus relational knowledge: semantic deficits in patients with Alzheimer's disease. Neuropsycho- 
logia, 44, 21-35.

Bayles, K. A., Tomoeda, C. K., \& Trosset, M. W. (1990). Naming and categorical knowledge in Alzheimer's disease: the process of semantic memory deterioration. Brain and Language, 39, 498-510.

Beber, B. C., da Cruz, A. N., \& Chaves, M. L. (2015). A behavioral study of the nature of verb production deficits in Alzheimer's disease. Brain and Language, 149, 128-134.

Bird, H., Howard, D., \& Franklin, S. (2000). Why is a verb like an inanimate object? Grammatical category and semantic category deficits. Brain and Language, 72, 246-309.

Bonilla, J. L., \& Johnson, M. K. (1995). Semantic space in Alzheimer's disease patients. Neuropsychology, 9, 345-353.

Bowles, N. L., Obler, L. K., \& Albert, M. L. (1987). Naming errors in healthy aging and dementia of the Alzheimer type. Cortex, 23, 519-524.

Cappa, S. F., Binetti, G., Pezzini, A., Padovani, A., Rozzini, L., \& Trabucchi, M. (1998). Object and action naming in Alzheimer's disease and frontotemporal dementia. Neurology, 50, 351-355.

Cho, N. H. (2002). Investigation of frequently used modern Korean language vocabulary. Seoul: National Institute of Korean Language.

d'Honincthun, P., \& Pillon, A. (2008). Verb comprehension and naming in frontotemporal degeneration: the role of the static depiction of actions. Cortex, 44, 834-847.

Dell, G. S. (1986). A spreading-activation theory of retrieval in sentence production. Psychological Review, 93, 283-321.

Druks, J., Masterson, J., Kopelman, M., Clare, L., Rose, A., \& Rai, G. (2006). Is action naming better preserved (than object naming) in Alzheimer's disease and why should we ask? Brain and Language, 98, 332-340.

Farah, M. J., \& McClelland, J. L. (1991). A computational model of semantic memory impairment: modality specificity and emergent category specificity. Journal of Experimental Psychology: General, 120, 339-357.

Ferretti, T. R., McRae, K., \& Hatherell, A. (2001). Integrating verbs, situation schemas, and thematic role concepts. Journal of Memory and Language, $44,516-547$.

Flanagan, K. J., Copland, D. A., Chenery, H. J., Byrne, G. J., \& Angwin, A. J. (2013). Alzheimer's disease is associated with distinctive semantic feature loss. Neuropsychologia, 51, 2016-2025.

Garrard, P., Ralph, M. A. R., Hodges, J. R., \& Patterson, K. (2001). Prototypicality, distinctiveness, and intercorrelation: analyses of the semantic attributes of living and nonliving concepts. Cognitive Neuropsychology, 18, 125174.
Grossman, M., \& Mickanin, J. (1994). Picture comprehension in probable Alzheimer's disease. Brain and Cognition, 26, 43-64.

Grossman, M., Mickanin, J., Onishi, K., \& Hughes, E. (1996). Verb comprehension deficits in probable Alzheimer's disease. Brain and Language, 53, 369-389.

Jin, C., Choi, H., \& Lee, J. Y. (2016). Usefulness of spontaneous speech analysis scales in patients with mild cognitive impairment and dementia of Alzheimer's type. Communication Sciences \& Disorders, 21, 284-294.

Jonkers, R., \& Bastiaanse, R. (2007). Action naming in anomic aphasic speakers: effects of instrumentality and name relation. Brain and Language, 102, $262-272$

Kang, Y., Na, D. L., \& Hahn, S. (1997). A validity study on the Korean minimental state examination (K-MMSE) in dementia patients. Journal of the Korean Neurological Association, 15, 300-308.

Kemmerer, D., \& Tranel, D. (2000). Verb retrieval in brain-damaged subjects: 1. Analysis of stimulus, lexical, and conceptual factors. Brain and Language, 73, 347-392.

Kim, H. H., \& Na, D. L. (1997). Korean Boston Naming Test (K-BNT). Seoul: Hakjisa.

Kim, H. H., Kim, E. Y., \& Na, D. L. (1997). Naming deficits in patients with dementia of the Alzheimer type: error analysis of Korean version-Boston naming test. Journal of Korean Neurology, 15, 1012-1021.

Kim, J. C., \& Lee, E. K. (2016). A comparison of word semantic comprehension ability in dementia patients with Alzheimer's disease: focused on a verb and an adjective descriptions. Journal of Speech-Language \& Hearing Disorders, 25, 37-44.

Kim, J. W., Hwang, J. H., Kim, S. R., \& Kim, H. (2013). Differences in attention and naming ability with age in the elderly. Journal of Speech \& Hearing Disorders, 22, 25-44.

Kim, J., Kim, H., Namkoong, K., Kim, S., \& Kim, D. (2006). Spontaneous speech traits in patients with Alzheimer's disease. Korean Journal of Communication Disorders, 11, 82-98.

Kim, K. H. (2003). Grade level vocabulary list. Seoul: Pagijung.

Kim, M., \& Thompson, C. K. (2000). Patterns of comprehension and production of nouns and verbs in agrammatism: implications for lexical organization. Brain and Language, 74, 1-25.

Kim, M., \& Thompson, C. K. (2004). Verb deficits in Alzheimer's disease and agrammatism: Implications for lexical organization. Brain and Language, $88,1-20$.

Kiss, K. (2000). Effect of verb complexity on agrammatic aphasic speakers' 
sentence production. In R. Bastiaanse \& Y. Grodzinsky (Eds.), Grammatical disorders in aphasia: a neurolinguistic perspective (pp. 123-151). London: Whurr Publishers.

Koenig, J. P., Mauner, G., \& Bienvenue, B. (2003). Arguments for adjuncts. Cognition, 89, 67-103.

Lee, G. J. (2002). Naming deficits in patients with dementia of the Alzheimer type (Master's thesis). Ewha Womans University, Seoul, Korea.

Lezak, M. D. (1995). Neuropsychological assessment (3rd ed.). Oxford: Oxford University Press.

MacKay, A. J., Connor, L. T., Albert, M. L., \& Obler, L. K. (2002). Noun and verb retrieval in healthy aging. Journal of the International Neuropsychological Society, 8, 764-770.

Martin, A., \& Fedio, P. (1983). Word production and comprehension in Alzheimer's disease: the breakdown of semantic knowledge. Brain and Language, 19, 124-141.

Masterson, J., Druks, J., Kopelman, M., Clare, L., Garley, C., \& Hayes, M. (2007). Selective naming (and comprehension) deficits in Alzheimer's disease? Cortex, 43, 921-934.

McKhann, G., Drachman, D., Folstein, M., Katzman, R., Price, D., \& Stadlan, E. M. (1984). Clinical diagnosis of Alzheimer's disease Report of the NINCDSADRDA Work Group* under the auspices of Department of Health and Human Services Task Force on Alzheimer’s Disease. Neurology, 34, 939939.

Miller, G. A., \& Fellbaum, C. (1991). Semantic networks of English. Cognition, 41, 197-229.

Morris, J. C. (1993). The Clinical Dementia Rating (CDR): current version and scoring rules. Neurology, 43, 2412-2414.

Ober, B. A., \& Shenaut, G. K. (1999). Well-organized conceptual domains in Alzheimer's disease. Journal of the International Neuropsychological Society, 5, 676-684.

Park, E. S., Jeong, O. R., \& Kang, S. K. (2005). A comparative study on the naming ability of content words in Alzheimer's disease patients with a focus on nouns and verbs. Journal of Speech \& Hearing Disorders, 14, 217228.
Parris, B. A., \& Weekes, B. S. (2006). Naming actions and objects in dementia. Brain and Language, 99, 130-131.

Parris, B. A., \& Weekes, B. S. (2001). Action naming in dementia. Neurocase, 7, 459-471.

Ramsay, C. B., Nicholas, M., Au, R., Obler, L. K., \& Albert, M. L. (1999). Verb naming in normal aging. Applied Neuropsychology, 6, 57-67.

Rhee, J., Antiquena, P., \& Grossman, M. (2001). Verb comprehension in frontotemporal degeneration: the role of grammatical, semantic and executive components. Neurocase, 7, 173-184.

Rips, L. J., Shoben, E. J., \& Smith, E. E. (1973). Semantic distance and the verification of semantic relations. Journal of Verbal Learning and Verbal Behavior, 12, 1-20.

Robinson, K. M., Grossman, M., White-Devine, T., \& D’esposito, M. (1996). Category-specific difficulty naming with verbs in Alzheimer's disease. Neurology, 47, 178-182.

Thompson, C. K., Lange, K. L., Schneider, S. L., \& Shapiro, L. P. (1997). Agrammatic and non-brain-damaged subjects' verb and verb argument structure production. Aphasiology, 11, 473-490.

Tulving, E. (1972). Episodic and semantic memory. Organization of Memory, 1, 381-403.

Tversky, A. (1977). Features of similarity. Psychological Review, 84, 327-352.

Vigliocco, G., Vinson, D. P., Damian, M. F., \& Levelt, W. (2002). Semantic distance effects on object and action naming. Cognition, 85, B61-B69.

Vinson, D. P., \& Vigliocco, G. (2002). A semantic analysis of grammatical class impairments: semantic representations of object nouns, action nouns and action verbs. Journal of Neurolinguistics, 15, 317-351.

Vinson, D. P., Vigliocco, G., Cappa, S., \& Siri, S. (2003). The breakdown of semantic knowledge: Insights from a statistical model of meaning representation. Brain and Language, 86, 347-365.

White-Devine, T., Grossman, M., Robinson, K. M., Onishi, K., \& Biassou, N. (1996). Verb confrontation naming and word-picture matching in Alzheimer's disease. Neuropsychology, 10, 495-503.

Williams, B. W., Mack, W., \& Henderson, V. W. (1989). Boston naming test in Alzheimer's disease. Neuropsychologia, 27, 1073-1079. 
Appendix 1. 대면이름대기과제의 도구 및 비도구동사 어휘목록

\begin{tabular}{|c|c|c|c|c|c|c|}
\hline \multirow{2}{*}{ 번호 } & \multicolumn{3}{|c|}{ 도구동사(N=20) } & \multicolumn{3}{|c|}{ 비도구동사 $(\mathrm{N}=20)$} \\
\hline & 항목 & 빈도순위 ${ }^{a}$ & 등급 ${ }^{b}$ & 항목 & 빈도순위 ${ }^{a}$ & 등급b \\
\hline 1 & 쓰다 & 169 & 1 & 넣다 & 219 & 1 \\
\hline 2 & 마시다 & 365 & 1 & 타다 & 260 & 2 \\
\hline 3 & 그리다 & 439 & 1 & 입다 & 354 & 1 \\
\hline 4 & 붙이다 & 705 & 1 & 넘다 & 476 & 1 \\
\hline 5 & 자르다 & 1,166 & 1 & 끌다 & 568 & 1 \\
\hline 6 & 뿌리다 & 1,348 & 1 & 던지다 & 621 & 1 \\
\hline 7 & 밀다 & 1,485 & 1 & 싣다 & 1,520 & 1 \\
\hline 8 & 바르다 & 1,497 & 1 & 따다 & 1,590 & 1 \\
\hline 9 & 붓다 & 1,841 & 1 & 누르다 & 1,599 & 1 \\
\hline 10 & 쏘다 & 2,418 & 1 & 밟다 & 1,919 & 1 \\
\hline 11 & 젓다 & 2,559 & 2 & 끼다 & 2,072 & 1 \\
\hline 12 & 털다 & 2,701 & 2 & 차다 & 2,223 & 1 \\
\hline 13 & 묶다 & 2,711 & 2 & 벗기다 & 2,499 & 2 \\
\hline 14 & 박다 & 2,830 & 1 & 줍다 & 2,781 & 1 \\
\hline 15 & 뜷다 & 3,113 & 1 & 당기다 & 3,140 & 2 \\
\hline 16 & 파다 & 3,168 & 1 & 꽃다 & 3,462 & 1 \\
\hline 17 & 베다 & 3,750 & 1 & 업다 & 3,940 & 2 \\
\hline 18 & 쓸다 & 4,443 & 2 & 뱉다 & 4,797 & 2 \\
\hline 19 & 빨다 & 5,761 & 1 & 짜다 & 5,057 & 1 \\
\hline 20 & 재다 & 6,130 & 2 & 찢다 & 5,416 & 2 \\
\hline
\end{tabular}


Appendix 2. 낱말-그림짝맞추기과제의 도구 및 비도구동사 어휘목록

\begin{tabular}{|c|c|c|c|c|c|c|c|c|}
\hline \multirow{3}{*}{ 번호 } & \multicolumn{4}{|c|}{ 도구동사(N=20) } & \multicolumn{4}{|c|}{ 비도구동사 $(\mathrm{N}=20)$} \\
\hline & \multirow{2}{*}{ 목표어휘 } & \multicolumn{3}{|c|}{ 방해자극어 } & \multirow{2}{*}{ 목표어휘 } & \multicolumn{3}{|c|}{ 방해자극어 } \\
\hline & & 의미관련 & 음운관련 & 무관어 & & 의미관련 & 음운관련 & 무관어 \\
\hline 1 & 쓰다 & 그리다 & 쏘다 & 들다 & 넣다 & 꽃다 & 놓다 & 털다 \\
\hline 2 & 마시다 & 먹다 & 맞추다 & 잡다 & 타다 & 달리다 & 따다 & 뱉다 \\
\hline 3 & 그리다 & 쓰다 & 가리다 & 넣다 & 입다 & 끼다 & 업다 & 바르다 \\
\hline 4 & 붙이다 & 누르다 & 무치다 & 타다 & 넘다 & 오르다 & 널다 & 팔다 \\
\hline 5 & 자르다 & 찢다 & 가리다 & 놓다 & 끌다 & 들다 & 끓다 & 물다 \\
\hline 6 & 뿌리다 & 틀다 & 부르다 & 끌다 & 던지다 & 차다 & 건지다 & 꽂다 \\
\hline 7 & 밀다 & 갈다 & 빌다 & 버리다 & 싣다 & 들다 & 신다 & 불다 \\
\hline 8 & 바르다 & 그리다 & 버리다 & 던지다 & 따다 & 꺾다 & 뜨다 & 팔다 \\
\hline 9 & 붓다 & 틀다 & 웃다 & 오르다 & 누르다 & 치다 & 구르다 & 자다 \\
\hline 10 & 쏘다 & 던지다 & 쓰다 & 끼다 & 밟다 & 누르다 & 뱉다 & 널다 \\
\hline 11 & 젓다 & 끌다 & 걷다 & 차다 & 끼다 & 입다 & 깨다 & 부르다 \\
\hline 12 & 털다 & 닦다 & 떨다 & 배다 & 차다 & 던지다 & 추다 & 열다 \\
\hline 13 & 묶다 & 매다 & 웃다 & 줍다 & 벗기다 & 찢다 & 버리다 & 줍다 \\
\hline 14 & 박다 & 치다 & 닦다 & 씹다 & 줍다 & 건지다 & 주다 & 타다 \\
\hline 15 & 뜷다 & 파다 & 꼻다 & 업다 & 당기다 & 잡다 & 담그다 & 틀다 \\
\hline 16 & 파다 & 뜷다 & 타다 & 꽃다 & 꽃다 & 넣다 & 꺾다 & 안다 \\
\hline 17 & 베다 & 썰다 & 개다 & 긁다 & 업다 & 들다 & 입다 & 뽑다 \\
\hline 18 & 쓸다 & 닦다 & 썰다 & 뱉다 & 뱉다 & 씹다 & 배다 & 찾다 \\
\hline 19 & 빨다 & 먹다 & 팔다 & 꺾다 & 짜다 & 널다 & 차다 & 떼다 \\
\hline 20 & 재다 & 세우다 & 자다 & 담그다 & 찢다 & 깨다 & 치다 & 넣다 \\
\hline
\end{tabular}


Appendix 3. 과제에 사용된 그림자료 예시

1) 대면이름대기과제

(1) 도구동사 '묶다'의 예

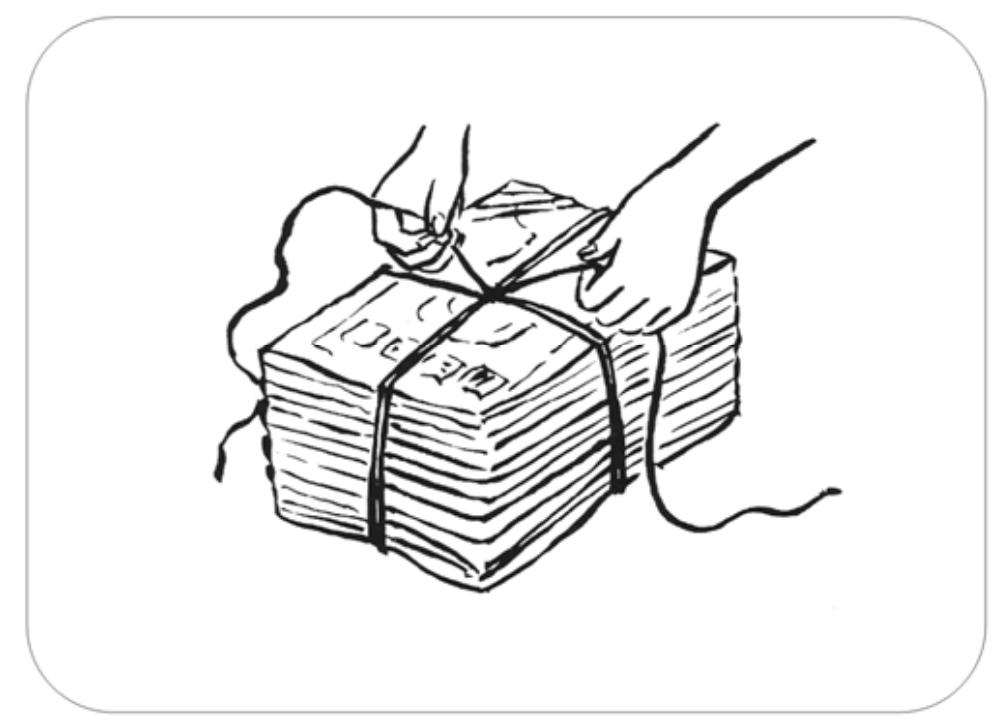

(2) 비도구동사 '짜다'의 예

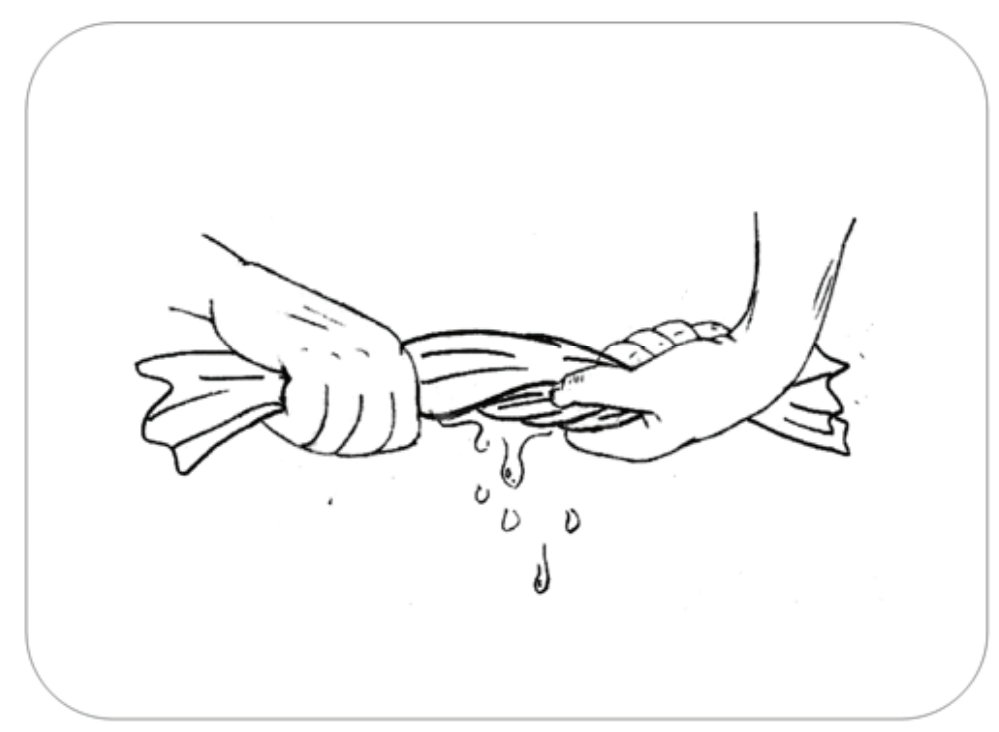


2) 낱말-그림짝맞추기과제

(1) 도구동사 '베다'의 예

(1)

(2)

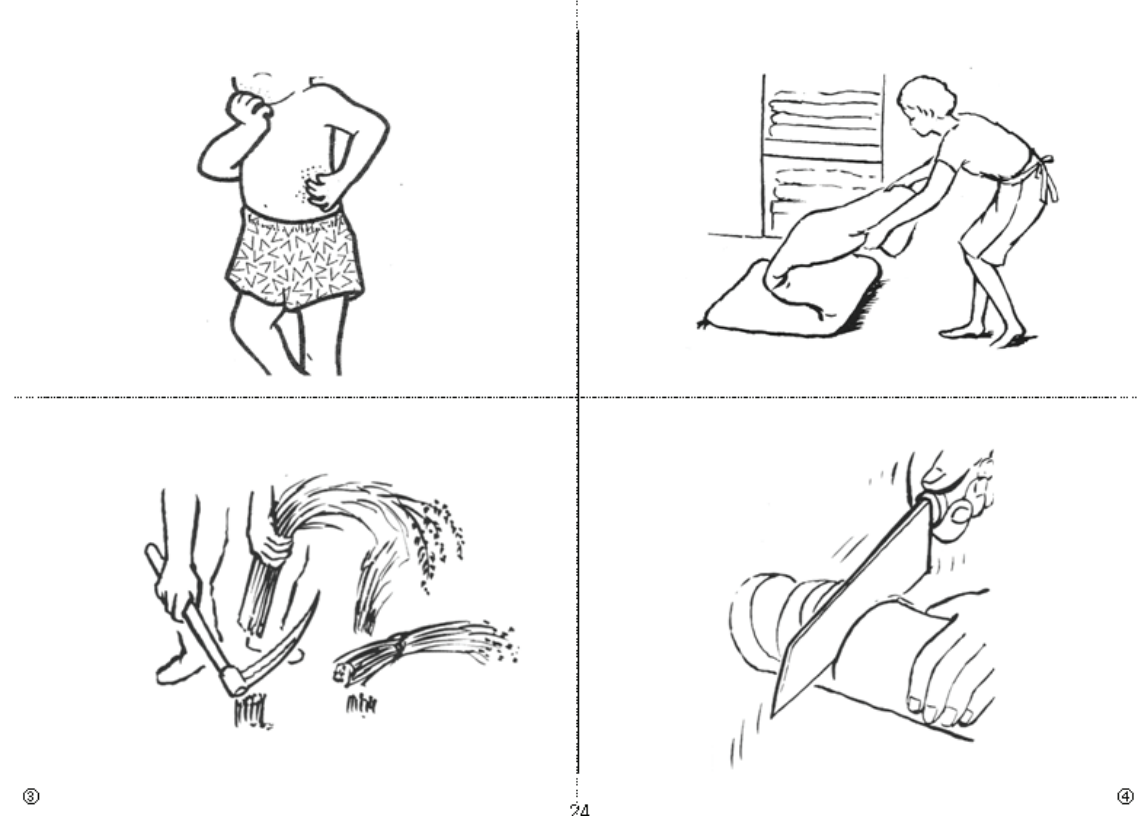

(2) 비도구동사 ‘누르다’의 예

(1)

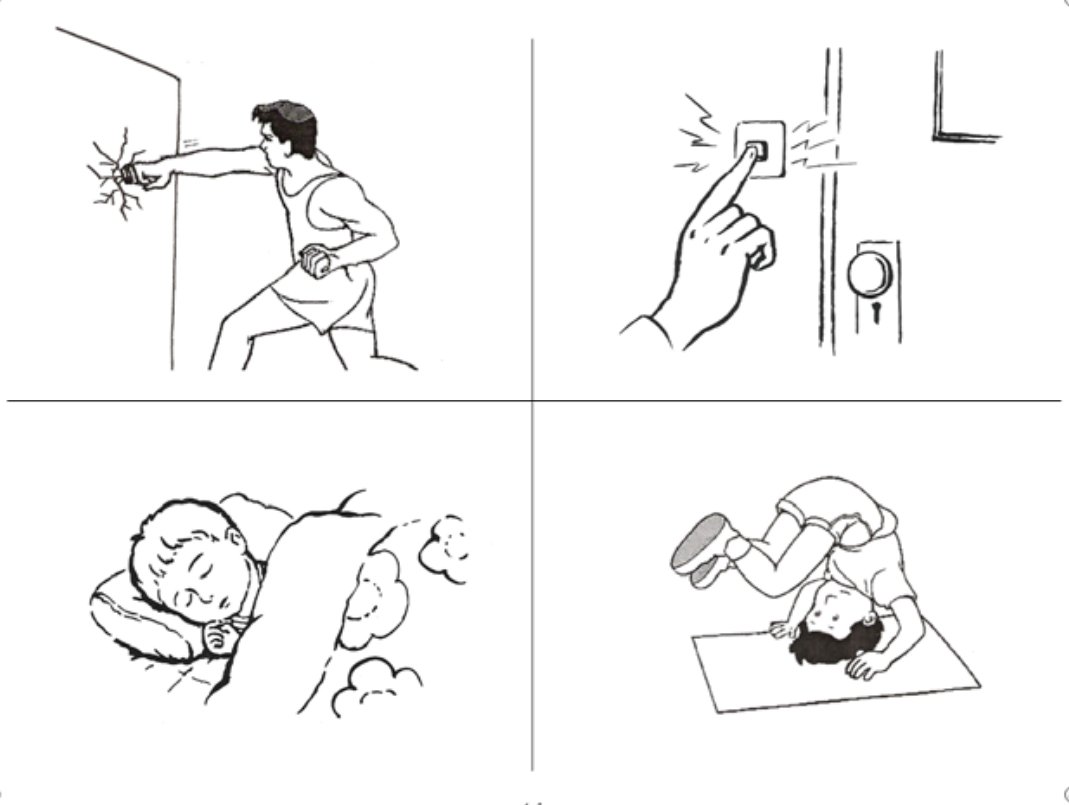




\section{국문초록}

\section{알츠하이머성 치매환자의 동사 이름대기와 이해: 동작동사의 도구성을 중심으로 신상은 ${ }^{1} \cdot$ 권미선 $^{2} \cdot$ 이재홍 ${ }^{2} \cdot$ 심현섭 $^{1}$ \\ ${ }^{1}$ 이화여자대학교 대학원 언어병리학과, ${ }^{2}$ 울산대학교 의과대학 서울아산병원 신경과}

배경 및 목적: 본 연구는 알츠하이머성 치매(Alzheimer's disease, $\mathrm{AD}$ ) 환자의 동사산출과 이해 과정에서 나타나는 의미지식의 손상에 대한 이해를 확장하고자 도구성에 초점을 맞추어 실시된 연구이다. 방법: 경도 및 중등도로 진단받은 $\mathrm{AD}$ 환자 12 명과 정상노인 12 명을 대상으로 동사 대면이름대기과제와 낱말-그림짝맞추기과제를 실시하였다. 도구동사 20 개와 비도구동사 20 개로 구성된 총 40 개의 항 목이 사용되었으며 모두 고빈도의 친숙한 어휘들로 구성하였다. 집단별로 과제유형이 주는 효과와 각 과제별 도구성 여부가 주는 효과 를 살펴보기 위하여 반복측정 이원분산분석과 함께 사후검정으로 독립표본 $t$-검정 및 대응표본 $t$-검정을 실시하였다. 결과: 집단과 과 제유형의 주효과 및 이들 간의 상호작용이 통계적으로 유의하였다. 즉, $\mathrm{AD}$ 집단이 정상노인집단보다 동사의 이해와 이름대기점수가 모 두 낮았으며 특히 이름대기과제의 점수차가 벌어지는 것으로 나타났다. 과제별로 살펴보면 동사이름대기과제에서 $\mathrm{AD}$ 집단이 도구와 비도구동사 모두에서 정상집단보다 낮은 수행을 보였으며 도구동사의 점수가 비도구동사보다 유의하게 낮았다. 그러나 낱말-그림짝맞 추기과제에서는 $\mathrm{AD}$ 집단이 정상노인집단보다 유의하게 낮은 수행을 보였으나 도구성의 주효과는 발견되지 않았다. 논의 및 결론: 본 연구 결과는 $\mathrm{AD}$ 환자가 의미기억 손상으로 인하여 동사의 이해와 산출에 결함을 보인다는 선행연구 결과를 도구성이라는 의미범주로 확장하였으며, 도구동사의 산출능력이 이해능력보다 더 손상되어 나타난다는 것을 보여주었다. 연구목표와 관련하여 자질-기반 프레 임워크(feature-based framework)에 기반한 동사와 사물 간의 의미자질 관계가 본 연구에서 논의되었다.

핵심어: 알츠하이머성 치매, 동사이름대기, 동사이해, 도구성, 의미기억

본 논문은 제 1 저자의 석사학위논문(2007)의 일부를 발췌한 것임.

\section{참고문헌}

강연욱, 나덕렬, 한승혜(1997). 치매환자들을 대상으로 한 K-MMSE의 타당도 연구. 대한신경과학회지, 15, 300-308.

김광해(2003). 등급별 국어교육용 어휘. 서울: 도서출판 박이정.

김정완, 김향희, 남궁기, 김세주, 김덕용(2006). 알츠하이머형 치매환자의 발화특성. 언어청각장애연구, 11, 82-98.

김정완, 황재호, 김수련, 김향희(2013). 정상 노인의 연령에 따른 주의력 및 이름대기 능력의 차이. 언어치료연구, 22, 25-44.

김지채, 이은경(2016). 알츠하이머 치매 환자의 의미이해능력 비교: 동사와 형용사를 중심으로. 언어치료연구, 25, 37-44.

김향희, 김은연, 나덕렬(1997). 알쯔하이머성 치매환자의 이름대기장애: 한국판 보스톤 이름대기검사상의 오류를 중심으로. 대한신경과학회지, 5 , 1012-1021.

김향희, 나덕렬(1997). 한국판 보스톤 이름대기 검사(K-BNT). 서울: 학지사.

박은실, 정옥란, 강수균(2005). 알츠하이머성 치매 환자의 내용어 명명하기에 관한 비교 연구: 명사와 동사를 중심으로. 언어치료연구, 14, 217-228.

이규정(2002). 알쯔하이머성 치매환자의 이름대기 장애에 관한 연구. 이화여자대학교 대학원 석사학위논문.

조남호(2002). 현대 국어 사용 빈도 조사: 한국어 학습용 어휘 선정을 위한 기초조사. 서울: 국립국어연구원.

진천, 최현주, 이준영(2016). 경도인지장애 및 알츠하이머형 치매 환자의 자발화 분석 척도의 유용성. 언어청각장애연구, 21, 284-294. 